\title{
Predicting Users' Responses of Public Utility Services - Multivariate and Neural Network Analysis - A Case Study
}

\author{
S. Sreedharana, Poornima G.R ${ }^{b}$, Meena Nairc, Genanew B.Worku ${ }^{d}$, Ananth Rao ${ }^{*}$, Wathiq Mansoor ${ }^{\dagger}$ \\ a Public Affairs Centre (PAC), Bangalore-India, sreedhar@pacindia.org \\ bProgramme Officer, PAC, Bangalore - India, poornima.gr@pacindia.org \\ cParticipatory Governance Research Group, PAC, Bangalore - India, meena@pacindia.org \\ ${ }^{d}$ Dubai Business School, University of Dubai, Dubai, United Arab Emirates, gbekele@ud.ac.ae \\ ${ }^{e}$ Dubai Business School, University of Dubai, Dubai, United Arab Emirates, arao@ud.ac.ae \\ ${ }^{f}$ College of Engineering and IT, University of Dubai, Dubai, wmansoor@ud.ac.ae \\ ${ }^{*}$ Corresponding author.
}

Received: 16 June 2017, revised: 4 September 2017, accepted: 7 September 2017, published: 9 April 2018

\begin{abstract}
This research addresses the problem of predicting the user's responses through multivariate choice (MVC) and neural network (NN) frameworks for predicting quality, quantity and overall User satisfaction of public water supply organization, BWSSB (Bangalore Water Supply and Sewerage Board) in Bangalore - India for policy initiatives. The MVC study identifies statistically significant factors that explain users' loyalty to express satisfaction and voice to express dissatisfaction. The MVC model correctly predicts $85 \%$ of satisfied customers across satisfaction dimensions. Wald test on 1940 responses confirms that there exits cross equation correlation across quality, quantity and overall Users' satisfaction dimensions and thus appropriateness of MVC framework over traditional logit for predicting the user responses. NN framework outperforms the econometric model with $94 \%$ correct classification of user responses. The study opens up potential research opportunities for applying the advanced analytical frameworks for predicting user responses in various public and private settings for Policy initiatives so that the service providers could improve their service delivery.
\end{abstract}

Key Words: Multivariate Choice Model, Neural Networks, Public Utility Service Provider, Econometric Model, Behavioural Responses, Big Data Analytics.

JEL Codes: H41, H44, O18, Q25

\section{INTRODUCTION}

Until recently, less interest has been shown to customer satisfaction by public administrations, especially in the case of public services, even though it is precisely in this sector that investigations on customer responses should be more useful. While private companies can be aware of customers' dissatisfaction with a product, because its purchasing decreases, a public enterprise providing a service and operating as a monopoly might well be unaware of the lack of satisfaction among its Users if these Users cannot switch to other providers, refuse or reduce the service, since Hirschman's "exit" becomes difficult or impossible (Hirschman 1970). Furthermore, a good knowledge of satisfaction for different aspects of a service in connection with the characteristics of its Users can suggest a multiple and more satisfactory provision of that service. In the absence of the market mechanisms of private ownership and competition, Brudney and England (1982) argue that satisfaction with the 'impacts' of services is significant in itself but also provides important information to policy makers. Therefore, a careful evaluation and monitoring of User satisfaction through survey responses using appropriate analytical tools could be useful in the public sector.

\subsection{Research problem and questions}


Many low income countries attempted to provide infrastructure services by forming state owned monopolies, as large scale provision of infrastructure was favored because of the economics of scale. But in recent decades, it has become clear that many public water monopolies are inefficient providers of utility services, resulting in poor service quality (McIntosh, 2003; Jamison et al, 2004; Hall, 2006; Das et al, 2010). The urban poor customers are often served by a wide range of service providers (such as water kiosks, water tankers) operating in the informal market and usually pay more to obtain water than when supplied from the public piped network. In the absence of competition (IUCN, 2010), utility customers have little option if the quality of service provision remains poor. Hirschman (1970) theory of exit, voice and loyalty states that; any individual, business firms and organizations under any socio-economic or political system, are subject to lapses that might range from efficient, virtuous, rational, law abiding, or otherwise functional behavior and failures of some institutions are bound to happen, no matter how well some actors in the society live up to it. It states further that "each society learns to live with certain amount of these failures, and in order to prevent these failures from transforming into a societal decay, forces must be marshaled within it, which will make the faltering actors revert back to the behavior required for it to function properly." Utility customers who are not happy with the service level can either do nothing about it or they can seek to improve the situation through voice. Predicting users' response to the services is a big problem which requires deep analysis of the responses through pattern recognition. The research question that addresses the research problem is: "How can the users' behavioral responses be correctly predicted for initiating appropriate policy initiatives in public sector"?

\subsubsection{Research aims and objectives}

The aims of the current research are to develop a multivariate choice (MVC) system and Neural Network for assessing behavioral aspects of User responses, apply the framework to a set of big data of public water utility in Bangalore as a case study in terms of service quality, and to identify the priority areas of service for improvement, from the users' point of view. To achieve these aims, the measurable objectives are:

1. Develop a multivariate choice (MVC) system and neural network (NN) framework to predict users' responses.

2. Identify factors that determine quality, quantity and overall User satisfaction of services of public water utility as a case study.

\subsubsection{Justification of the Research}

Service quality has been explored in the past by numerous researchers with varying perspectives, but majority of these studies have focused on organizations in a competitive market (Parasuraman et al, 1985, 1988, 1994; Zeithaml et al, 1988, 1990 and 2003; Cronin and Taylor, 1992; Teas, 1993) to the detriment of organizations in a monopoly. There is a need to study service quality within the context of a monopoly in a water service domain, considering all processes and operations associated with the delivery of product and customer services in low income economies. The needs of the consumers are not often considered by governments and service providers (Sohail and Cavil, 2006; Thampi, 2005). The customer voice has been slow to develop in the water sector, unlike other sectors of the economies such as telecom and energy (Clarke and Wallsten, 2003), where consumer organizations have demanded accountability from marketers and service providers. Also, the important service quality attributes perceived by customers vary from sector to sector (Kim and Kang, 1995; Baker and Tremolet, 2003). A better understanding of customer satisfaction and how this can be measured is therefore, required to provide a prominent role for customers to lead to an efficient water supply service. Further, the study helps fill a void in the literature ${ }^{1}$.

\subsubsection{Organization of the paper}

Section 2 reviews the literature in analyzing public services satisfaction. Section 3 lays down the conceptual framework. Section 4 discusses the methodology and development of alternative models for assessing customers' satisfaction for public utility services. Section 5 analyzes the model results. Section 6 concludes the paper with limitations and directions for future research.

\section{LITERATURE REVIEW}

\footnotetext{
${ }^{1}$ The paper is also motivated by ready availability of primary data from the provider through a long-term research collaboration. The study findings open opportunities to similar public utility entities that face efficiency issues.
} 
There is a growing concern about the performances of public utilities responsible for supplying potable water and treating sewage (Khatri and Vairavamorthy, 2007). Faced with difficulties of maintaining aging infrastructure in times of tightening financial constraints, problems are associated with service quality and reliability (Hall, 2006; Renzetti \& Dupont, 2003). The general public in particular and the World Bank in general are concerned with the increasing failure of the public water utilities in developing countries to provide water supply; and the alternative small scale private water delivery systems (informal service providers), gives much cause for concern. It is therefore worrisome that the developing countries population, which accounts for $76 \%$ of the world population and constitutes an important part of the global economy (Ramamurti, 1992, Khatri and Vairavamorthy, 2007) is lagging behind in the Millennium Development Goals (MDG) to halve the population of people without sustainable access to safe drinking water and sanitation. There is also a growing need to develop satisfaction indicators for objectively measuring and monitoring the service quality of public water utilities in low income countries, from the customer's point of view over a period of time (Myhal et al, 2008). To successfully measure the service quality of water service providers, quantifiable and verifiable performance indicators are required through independent external scrutiny of service provider's measurement and reporting systems, Meyrick (2002). Kaufmann \& Lowry (2002), however posit that service quality indicators should satisfy four criteria: they should be related to the aspects of service that customers value; they should focus on monopoly services; Utilities should be able to affect the measured quality; and the indicators should not ignore pockets of service quality problems. RATER model defines five dimensional attributes derived from collapsing the original ten SERVQUAL components (Reliability, Assurance, Tangibles, Empathy, and Responsiveness) have been found to be relevant to most organizations and service sectors, although the importance of each dimension will vary from industry to industry (Parasuraman, 1988). Data are collected through a sample of customers who respond to a series of questions, based on around a number of key services dimensions. In this research, we use a modified framework suitable to monopoly water service provider as in Figure 3.1. A meta-analysis of the methodologies most used in the last few years to evaluate User satisfaction with public services and their characteristics are summarized in Table 2.1.

Table 2.1. Meta-analysis of methodologies to analyze behavioral responses (satisfaction) for public services.

\begin{tabular}{|c|c|c|c|}
\hline Methodology & Category & Characteristics & Early Research Studies \\
\hline $\begin{array}{l}\text { Logit, probit } \\
\text { and linear } \\
\text { regression }\end{array}$ & $\begin{array}{l}\text { Model- } \\
\text { based }\end{array}$ & $\begin{array}{l}\text { Dependence analysis. Satisfaction is explained } \\
\text { by some hypothesized determinants. Only one } \\
\text { response variable (one item at a time) is } \\
\text { considered }\end{array}$ & $\begin{array}{l}\text { Manzi and Ferrari (2014) } \\
\text { Cameron and Trivedi (2005) } \\
\text { Jilke and Van De Walle (2013) } \\
\text { Fiorio and Florio (2011) }\end{array}$ \\
\hline $\begin{array}{l}\text { Multilevel } \\
\text { models (ML) }\end{array}$ & $\begin{array}{l}\text { Model- } \\
\text { based }\end{array}$ & $\begin{array}{l}\text { Dependence analysis. Satisfaction is still } \\
\text { explained by some hypothesized determinants } \\
\text { as above but at different levels, e.g. at } \\
\text { individual and country levels. Useful for } \\
\text { hierarchical data. Only one response variable } \\
\text { (one item at a time) is considered }\end{array}$ & $\begin{array}{l}\text { Conway and Nicoletti (2006) } \\
\text { Bacchiocchi, Florio, Gambaro } \\
\text { (2011). } \\
\text { Fiorio et al. (2007) } \\
\text { Clifton, Díaz-Fuentes (2010) } \\
\text { Rahmqvist and Bara (2010) }\end{array}$ \\
\hline $\begin{array}{l}\text { Nonlinear } \\
\text { principal } \\
\text { component } \\
\text { analysis } \\
\text { (NPCA) }\end{array}$ & $\begin{array}{l}\text { Synthetic } \\
\text { measures } \\
\text { \&composite } \\
\text { indicators }\end{array}$ & $\begin{array}{l}\text { The focus is on measurement. More items } \\
\text { (aspects) of satisfaction can be taken into } \\
\text { consideration and weighted accordingly. Level } \\
\text { of satisfaction, importance of items and optimal } \\
\text { quantifications of answers are determined }\end{array}$ & $\begin{array}{l}\text { Ferrari, Annoni, and Manzi } \\
(2010) \\
\text { Gifi (1990) } \\
\text { Michailidis \& De Leeuw (1998) } \\
\text { Ferrari and Barbiero (2011) }\end{array}$ \\
\hline $\begin{array}{l}\text { Rasch model } \\
\text { (RM) }\end{array}$ & $\begin{array}{l}\text { Synthetic } \\
\text { measures \& } \\
\text { composite } \\
\text { indicators }\end{array}$ & $\begin{array}{l}\text { The focus is on measurement. Level of } \\
\text { satisfaction and quality of items (aspects) of } \\
\text { satisfaction can be assessed }\end{array}$ & \\
\hline $\mathrm{RM}+\mathrm{NPCA}$ & $\begin{array}{l}\text { Synthetic } \\
\text { measures \& } \\
\text { composite } \\
\text { indicators }\end{array}$ & $\begin{array}{l}\text { The complementary use of RM and NPCA } \\
\text { allows for the joint representation of quality and } \\
\text { importance of items in order to provide a set of } \\
\text { indicators to decision-makers }\end{array}$ & Rasch (1960) \\
\hline $\mathrm{NPCA}+\mathrm{ML}$ & $\begin{array}{l}\text { Synthetic } \\
\text { measures \& } \\
\text { composite } \\
\text { indicators + } \\
\text { models }\end{array}$ & $\begin{array}{l}\text { Both synthesis and explanatory analyses are } \\
\text { considered. The ML model is applied on a } \\
\text { synthetic measurement of satisfaction obtained } \\
\text { via NPCA }\end{array}$ & \\
\hline $\begin{array}{l}\text { Bayesian } \\
\text { networks }\end{array}$ & $\begin{array}{l}\text { Model- } \\
\text { based }\end{array}$ & $\begin{array}{l}\text { Models of cause and effect. Only one response } \\
\text { variable is processed at a time }\end{array}$ & $\begin{array}{l}\text { Salini and Kenett (2009) } \\
\text { Annoni (2007) }\end{array}$ \\
\hline
\end{tabular}




\begin{tabular}{|c|c|c|c|}
\hline Averaging & $\begin{array}{l}\text { Synthetic } \\
\text { and } \\
\text { comparative } \\
\text { tools }\end{array}$ & $\begin{array}{l}\text { Immediate synthetic indicator. Comparative } \\
\text { analysis based on conditional mean values of } \\
\text { observations }\end{array}$ & $\begin{array}{l}\text { Annoni and Brüggemann (2009) } \\
\text { Clifton and Díaz-Fuentes (2010) }\end{array}$ \\
\hline $\begin{array}{l}\text { PLS (Partial } \\
\text { Least } \\
\text { Square } \\
\text { Method) }\end{array}$ & $\begin{array}{l}\text { Model } \\
\text { based }\end{array}$ & Structured Equation Modeling & $\begin{array}{l}\text { Wold } 1982 \\
\text { Tenenhaus et al. } 2005\end{array}$ \\
\hline LISREL & $\begin{array}{l}\text { Model } \\
\text { based }\end{array}$ & Linear Structured Relationship & $\begin{array}{l}\text { Jöreskog 1970; } \\
\text { O'Brien and Homer } 1987\end{array}$ \\
\hline ANN & $\begin{array}{l}\text { Model- } \\
\text { based }\end{array}$ & $\begin{array}{l}\text { Artificial Neural Network for Water Demand } \\
\text { Forecasting (WDF) }\end{array}$ & $\begin{array}{l}\text { Jain et al. (2001) } \\
\text { Jain and Ormsbee (2002) } \\
\text { Bougadis et al. (2005) } \\
\text { Adamowski (2008) }\end{array}$ \\
\hline
\end{tabular}

In this study, we adopt new analytical tools such as multivariate choice (MVC) model and neural network as they found to be superior to traditional logit methodology to predict the behavioral aspects of the users. In section 4 we provide the evidence to superiority to these new approaches and compare the superiority of these frameworks over the traditional Logit model.

\section{CONCEPTUAL FRAMEWORK}

Exit, voice and loyalty are theoretical concepts (Hirschman, 1970; Withey and Cooper, 1989), which elaborates on two essential options in an event of organizational decline. Hirschman hypothesized that if a firm's product and services decline in quality, customers have three alternative responses; Exit-Voice-Loyalty trilogy. Exit occurs when customers stop buying a firms' product and services, causing drop in revenue, and forcing management to correct whatever faults that led to exit; voice, when customers express their dissatisfaction, forcing management to search for causes and remedy causes of dissatisfaction attempting to improve it through communication of complaint, grievance or proposal for a change; and loyalty on the other hand, reflects the attachment people have for organizations, which inevitably affects their willingness to exit or voice out their grievances. Hirschman philosophized that Individuals, business firms and organizations under any socioeconomic or political system are subject to lapses that might range from efficient, virtuous, rational, law abiding or otherwise. Hirschman further asserts that functional behavior and failures of some institutions are bound to happen, no matter how well some actors in the society live up to; and that each society learns to live with a certain amount of these failures. In order to prevent these failures from transforming into a societal decay, forces must be marshaled within the society itself to make the faltering actors revert back to the behavior required for it to function properly. While Hirschman's) exit, voice, and loyalty focused primarily on dissatisfaction with the performance of an organization, subsequent work addressed the application of exit and voice in diverse ways as the theory of household behavior (Katz, 1997, Gershuny et al, 2005; Hirschman, 1978; Rogowski, 1998). In principle, voice and exit are applicable to organizations in a competitive market when quality of products and service deteriorates, but exit is not always feasible in a monopoly market structure. The absence of exit options in an organization can sharply increase the possibility of the voice option being widely and effectively taken up by its customers. Exit is associated with the market and depends on choice in service provision and so unthinkable in a monopoly. Andreassen and Lindestad (1998) state that people might be loyal to service provider for three reasons: high switching barriers, lack of alternatives or customer satisfaction. In Hirschman's model loyalty is ambiguous. Lowery et al (1992) however, present loyalty as positive construct when customers are satisfied with services or belief that service providers will sort out any problem that arise; and negative construct when customers are indifferent to any situation which can be a sign of a possible neglect of services by service provider. The interplay of loyalty can however affect the cost benefit analysis of whether to use exit or voice. By understanding the relationship between exit and voice and the interplay that loyalty has with choice as in Figure 3.1 , service providers can develop the means to better address their customers' concerns and thereby effect improvement in service delivery.

In Figure 3.1 level one, the service culture of public water service providers impacts service quality. In the second level of the framework, the service quality provided by the water service provider is determined by their expectation and service encounter (pre and after sales experience) of the customers. The demographic characteristic of the customers, which includes Service area; Type of dwelling; Size of household; Gender; Age group; Educational level and Income group are equally important to determine the level of their influence 
(Omonona, 2009). In the third level, quality between the technical aspects of service delivery (known as Product quality) and the functional aspect (known as the customer experience) of service delivery is distinguished. Functional quality refers to the service User's definition of quality, which is a more subjective concept (Myers and Lacey, 1996). In the fourth level, the level of customer (dis)satisfaction can easily be used to detect the variance in the quality of service by those with non-technical expertise, such as the customer groups and development agencies, using identified customer satisfaction indicators. In level five, customers whose expectations are not met and are dissatisfied with the level of service provided, have the option of voicing their dissatisfaction through a voice mechanism available or exit.

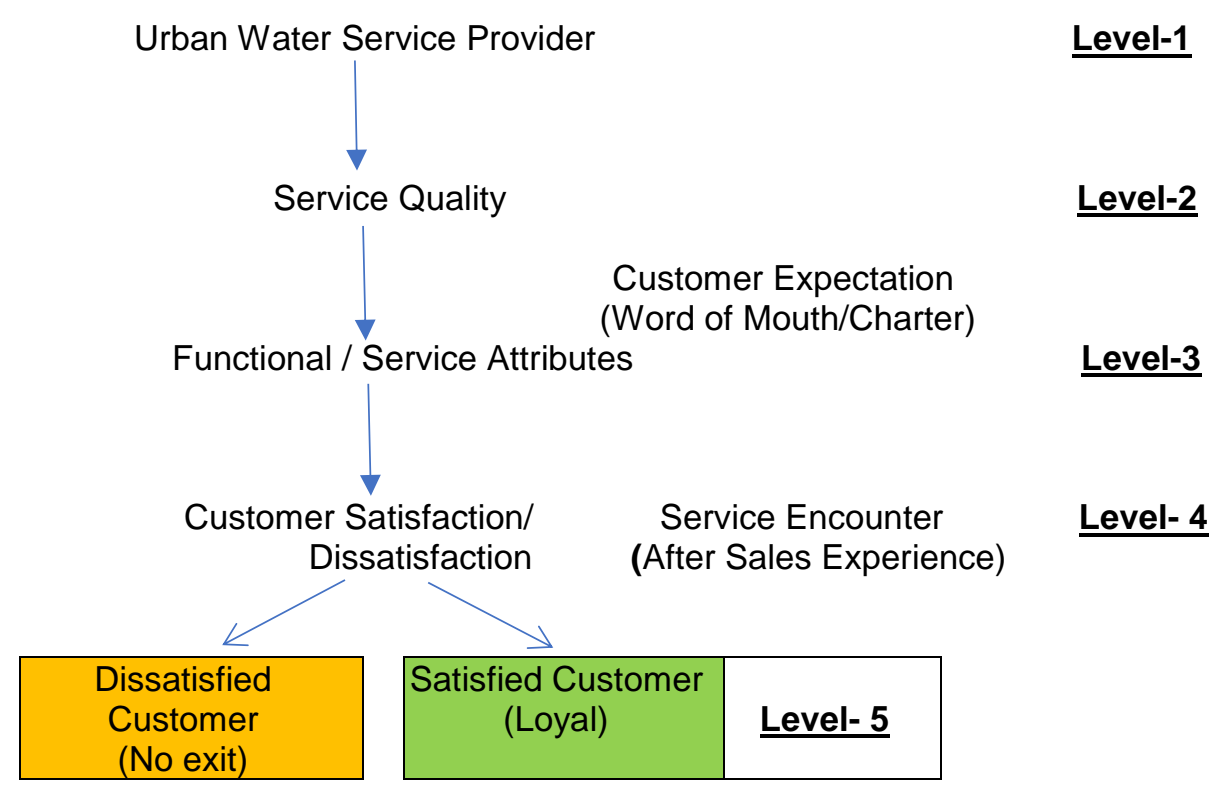

Figure 3.1: Conceptual Framework

\section{METHODOLOGY}

\subsection{Model Development}

As stated in section 1, this research focuses on predicting Users' behavioural responses of exit, voice and loyalty discussed in section 2, in the context of public water supply service provider. We focus on new analytical tools such as Multivariate Choice Model (MVC- not applied so far in Users' satisfaction context in the past as in Table 2.1) and check if this MVC specification is appropriate through robust Wald Test compared to traditional logit model. We also develop an alternative neural network (NN) to predict user's behavioral responses through pattern recognition which is devoid of econometric assumptions.

\subsubsection{Multivariate Choice (MVC) System Model}

An extension of the probit/logit model, MVC allow more than one logit equation to be handled in a system context, with correlated disturbances, in the same spirit as the seemingly unrelated regressions (SUR) model. The general specification for a three-equation model would be:

$$
\begin{gathered}
\mathrm{Y}_{1}^{*}=\mathrm{X}_{1}^{\prime} \beta_{1}+\varepsilon_{1}, \quad \mathrm{Y}_{1}=1 \text { if } \mathrm{Y}_{1}^{*}>0,0 \text { otherwise } \\
\mathrm{Y}_{2}^{*}=\mathrm{X}_{2}^{\prime} \beta_{2}+\varepsilon_{2}, \quad \mathrm{Y}_{2}=1 \text { if } \mathrm{Y}_{2}^{*}>0,0 \text { otherwise } \\
\mathrm{Y}_{3}^{*}=\mathrm{X}_{3}^{\prime} \beta_{3}+\varepsilon_{3}, \quad \mathrm{Y}_{3}=1 \text { if } \mathrm{Y}_{3}^{*}>0,0 \text { otherwise } \\
E\left[\varepsilon_{1} \mid X_{1}, X_{2}, X_{3}\right]=E\left[\varepsilon_{2} \mid X_{1}, X_{2}, X_{3}\right]=E\left[\varepsilon_{3} \mid X_{1}, X_{2}, X_{3}\right]=0 \\
\operatorname{Var}\left[\varepsilon_{1} \mid X_{1}, X_{2}, X_{3}\right]=\operatorname{Var}\left[\varepsilon_{2} \mid X_{1}, X_{2}, X_{3}\right]=\operatorname{Var}\left[\varepsilon_{3} \mid X_{1}, X_{2}, X_{3}\right]=1, \text { and }
\end{gathered}
$$




$$
\operatorname{Cov}\left[\varepsilon_{1}, \varepsilon_{2}, \varepsilon_{3} \mid X_{1}, X_{2}, X_{3}\right]=\rho
$$

where $Y_{1}^{*}$ refers to Users Quantity satisfaction. If the water supply meets their daily requirement, there is more satisfaction. $Y_{2}^{*}$ refers to Users Quality satisfaction. User is more satisfied if the water is drinkable. $Y_{3}^{*}$ refers to Users Overall satisfaction. User is more satisfied if the cumulative effect of all services considered is satisfactory.

\subsubsection{Neural Networks (NN)}

Forecasting, classification of risk, and dimensionality reduction or distillation of information from dispersed signals in the market, are three tools for effective management and broader decision making in volatile economies with "noisy" data. If we assume that our real-world observations come from a linear data generating process, that most shocks are from an underlying normal distribution and represent small deviations around a steady state, then the standard tools of classical regression are perfectly appropriate. However, making use of the linear model with normally generated disturbances may lead to serious misspecification if the real world deviates significantly from these assumptions of linearity and normality. Neural network methods, coming from the brain science of cognitive theory and neurophysiology, offer a powerful alternative to linear models for forecasting, and classification in behavioural science. All too often, we use the coefficients obtained from past data to fit new data and make predictions, classification, and dimensionality reduction decisions for the future. As the saying goes, life must be understood looking backwards, but must be lived looking forward. The past is certainly helpful for predicting the future, but we have to know which approximating models to use, in combination with past data, to predict future events. The success of any strategy depends on how well the forecasts guiding the decision makers work.

The appeal of the neural network approach lies in its assumption of bounded rationality: when we forecast in volatile emerging markets, we are approximating the expectations of others. Market participants are thus engaged in a learning process, continually adapting prior subjective beliefs from past mistakes. What makes the neural network approach so appealing in this respect is that it permits threshold responses by economic decision makers to changes in policy or exogenous variables ${ }^{2}$. In the neural network model, one is not making any specific hypothesis about the values of the coefficients to be estimated in the model, nor, for that matter, any hypothesis about the functional form relating the observed repressor " $x$ "to an observed output " $y$ ". Most of the time, we cannot even interpret the meaning of the coefficients estimated in the neural network, at least in the same way we can interpret estimated coefficients in ordinary econometric models, with a well-defined functional form. In that sense, the neural network differs from the usual econometrics, where considerable effort is made to obtain accurate and consistent, if not unbiased, estimates of particular parameters or coefficients. Similarly, when nonlinear models are used, too often economists make use of numerical algorithms based on assumptions of continuous or "smooth" data. All too often, these methods break down, or one must make use of repeated estimation, to make sure that the estimates do not represent one of several possible sets of local optimum positions. Various sectors of emerging markets, in particular, with a great deal of innovation and change, represent a fertile ground for the use of neural network for two reasons, which are interrelated. One is that the data are often very noisy, due either to the thinness of the markets or to the speed with which news becomes dispersed, so that there are obvious asymmetries and nonlinearities that cannot be assumed away. Second, in many instances, the players in these markets are themselves in a process of learning, by trial and error, about policy news or about legal and other changes taking place in the organization of their markets. The parameter estimates of a neural network, by which market participants forecast and make decisions, are themselves the outcome of a learning and search process.

\subsubsection{Neural Network (NN) Architecture}

Like the linear and polynomial approximation methods in econometrics, a neural network relates a set of input variables $\left\{x_{i}\right\}, i=1, \ldots, k$, to a set of one or more output variables, $\left\{y_{j}\right\}, j=1, \ldots, k$. The difference between a $\mathrm{NN}$ and the other approximation methods is that the neural network makes use of one or more hidden layers, in which the input variables are squashed or transformed by a special function, known as a logistic or log sigmoid transformation. While this hidden layer approach may seem esoteric, it represents a very efficient way to model nonlinear statistical processes. Feedforward Network in Figure 4.1 illustrate the architecture on a NN with one hidden layer containing two neurons, three input variables $\left\{X_{i}\right\}, i=1,2,3$, and one output $y$.

\footnotetext{
${ }^{2}$ For example, if the interest rate rises from 3 percent to 3.1 or 3.2 percent, there may be little if any reaction by investors. However, if the interest rate continues to increase, investors will take notice, more and more. If the interest rate crosses a critical threshold, for example, of 5 percent, there may be a massive reaction or "meltdown," with a sell-off of stocks and a rush into government securities. The basic idea is that reactions of economic decision makers are not linear and proportionate, but asymmetric and nonlinear, to changes in external variables.
} 
Figure 4.1. Feedforward neural network

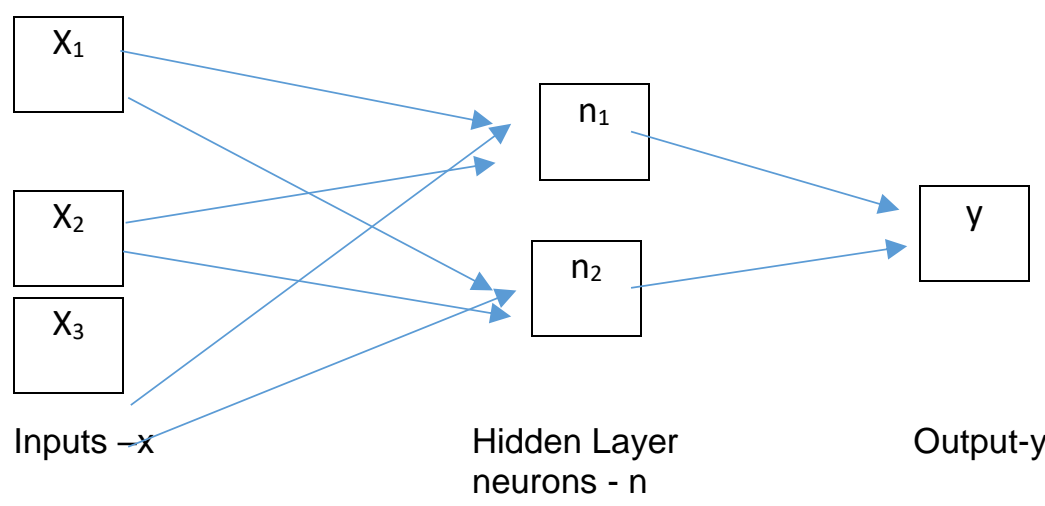

We see parallel processing in this network. In addition to the sequential processing of typical linear systems, in which only observed inputs are used to predict an observed output by weighting the input neurons, the two neurons in the hidden layer process the inputs in a parallel fashion to improve the predictions. The connectors between the input variables, often called input neurons, and the neurons in the hidden layer, as well as the connectors between the hidden-layer neurons and the output variable, or output neuron, are called synapses ${ }^{3}$. This single-layer feedforward or multi-perceptron network with one hidden layer is the most basic and commonly used neural network in behavioural economic and financial applications. More generally, the network represents the way the human brain processes input sensory data, received as input neurons, into recognition as an output neuron. As the brain develops, more and more neurons are interconnected by more synapses, and the signals of the different neurons, working in parallel fashion, in more and more hidden layers, are combined by the synapses to produce more nuanced insight and reaction ${ }^{4}$. In behavioural finance \& economic applications, the combining of the input variables into various neurons in the hidden layer has another interpretation. Quite often we refer to latent variables, such as expectations, as important driving forces in markets and the economy as a whole ${ }^{5}$. While it is often possible to obtain survey data of expectations at regular frequencies, such survey data come with a time delay. There is also the problem that how respondents reply in surveys may not always reflect their true expectations. The use of the NN to model the process of decision making is based on the principle of functional segregation, which Rustichini et al. (2002) define as "not all functions of the brain are performed by the brain as a whole". A second principle, called the principle of functional integration, states that "different networks of regions (of the brain) are activated for different functions, with overlaps over the regions used in different networks" [Rustichini et al. (2002), p. 3]. Making use of experimental data and brain imaging, they offer evidence that subjects make decisions based on approximations, particularly when subjects act with a short response time. They argue for the existence of a "specialization for processing approximate numerical quantities" [Rustichini et al. (2002), p. 16].

In a more general econometric framework, NN approximation is a sieve estimator. In the univariate case, with one input $\mathrm{x}$, an approximating function of order $\mathrm{m}, \Psi \mathrm{m}$, is based on a non-nested sequence of approximating spaces:

$$
\Psi_{m}=\left[\Psi_{m}, 0(X), \Psi_{m}, 1(X), \ldots, \Psi_{m}, m(X)\right]
$$

Beresteanu (2003) points out that each finite expansion $\left\{\Psi_{m}, 0(X), \Psi_{m}, 1(X), \ldots, \Psi_{m}, m(X)\right\}$, can potentially be based on a different set of Jump Connections. One alternative to the pure feedforward network or sieve network is a feedforward network with jump connections, in which the inputs $x$ has direct linear links to output $y$, as well as to the output through the hidden layer of squashed functions as in Figure 4.6.

\footnotetext{
${ }^{3}$ Most problems we work with, fortunately, do not involve a large number of neurons engaging in parallel processing, thus the parallel processing advantage, which applies to the way the brain works with its massive number of neurons, is not a major issue.

${ }^{4}$ Of course, very simple input sensory data, such as the experience of heat or cold, need not lead to processing by very many neurons in multiple hidden layers to produce the recognition or insight that it is time to turn up the heat or turn on the air conditioner. As experiences of input sensory data become more complex or diverse, more hidden neurons are activated, and insight as well as decision is a result of proper weighting or combining signals from many neurons, perhaps in many hidden layers. A commonly used application of this type of network is in pattern recognition in neural linguistics, in which handwritten letters of the alphabet are decoded or interpreted by networks for machine translation.

${ }^{5}$ Keynes referred quite often to "animal spirits" of investors in times of boom and bust, and we often refer to bullish (optimistic) or bearish (pessimistic) markets.
} 
Figure 4.2. Feedforward neural network with jump connections

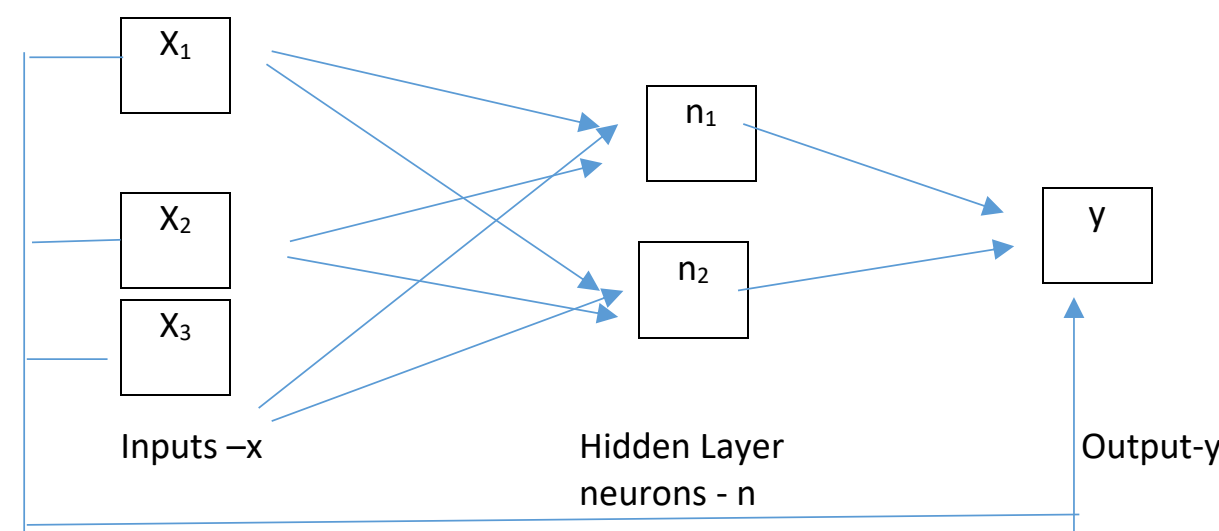

\subsection{Application of MVC and NN Models - Public Affairs Center (PAC-Bangalore) - A Case Study}

Public Affairs Centre (PAC) is a leading not-for-profit independent NGO think-tank, dedicated for mobilizing a demand for good governance in India ${ }^{6}$ and 7 . In 2014-15, PAC carried out an assessment of quality of services of BWSSB $^{8}$ using the Citizen Report Card (CRC) approach. The survey included 2057 Users from all subdivision, geographical, and all income strata. PAC provided to us the data with a request to apply advanced analytical tools such as MVC and NN for predicating Users responses. We postulate that these tools are unique and innovative artificial intelligence in nature which are the current research trends in Big Data Analytics and have the potential for replicating similar research across public services in UAE and the developing economies for improving the quality of public services.

To achieve the primary research question, data samples at six concept levels was used as in Table 4.1. Table 4.2 summarises the index of variables used in the analysis.

\subsubsection{Primary Research Design \& Preliminary Results}

Median Insights and Research, one of the social and market research organizations (based in Bangalore) conducted the field survey. The research design involved in-depth scoping exercises among a small sample of Users and providers to collect information, which was then used to populate three types of data collection instruments - for consumers, for senior-level BWSSB officials and other BWSSB personnel. The full report was qualitative and basic and is available by accessing the link: http://pacindia.org/.

\subsubsection{User Profile and Usage Pattern}

Of the total 2057 respondents $-72.5 \%$ were male and $27.5 \%$ were female. Average size of houses covered around 1001 sq. ft. $41 \%$ of the Users had houses with ground floor only. Average monthly income of per household - INR 20,800 and expenditure INR10,300. For $65 \%$ households, Cauvery river water through tap at home is the main source of BWSSB water supply. Other sources used include public tap (20\%) and public hand pumps (10\%).

Table 4.1: Definitions of Conceptual Variables in a Monopoly Public Water Service Provider

\section{Concepts-Level Indicative Rationale for the relationship hypothesized Hypothesis}

\footnotetext{
${ }^{6}$ PAC's tools are designed towards allowing citizen-monitoring of public service delivery. Its most famed innovation, the Citizen Report Card (CRC) approach, has received much acclaim globally, earning extensive mention in the World Bank's World Development Report 2004, 'Making Services Work for Poor People'. PAC's work is primarily organized around the premise that an informed and active citizenry is the key to improved governance. The CRC is a simple and credible tool to provide systematic feedback to public agencies about various quantitative and qualitative aspects of their performance. CRCs elicit information about Users' awareness, access, usage and satisfaction with public services ${ }^{6}$.Some of the project completed with Public Grant included those funded by World Bank.

7 Various government departments including the Karnataka State Police Department (GoK), BESCOM, Karnataka Jnana Aayoga, and the State Planning Board (GoK), Sarva Shiksha Abhiyan (GoK); Madhya Pradesh Urban Development Department, Bihar Urban and Rural Development Departments (PAF), for the Delhi government (PAF).

8 BWSSB stands for Bangalore Water Supply and Sewage Board - a Public Utility Entity of government of Karnataka.

91 US\$ = Average INR 67 in 2014-15
} 


\begin{tabular}{|c|c|c|c|}
\hline 1 & $\begin{array}{l}\text { Demography/ } \\
\text { Occupant }\end{array}$ & $\begin{array}{c}\mathrm{H} 1 \\
\text { (Negative) }\end{array}$ & $\begin{array}{l}\text { User satisfaction declines if the demography is unfavourable } \\
\text { - like rented house (since the household is not the owner and has to be } \\
\text { contented with the available space, uncomfortable layout of facilities) } \\
\text { - living in higher floors (since it requires water supply at higher pressure } \\
\text { from the ground level) } \\
\text { - low occupation type (since skills level are low), } \\
\text { - low education level (family weak economic status which reduces } \\
\text { opportunities for higher education), } \\
\text { - large family size (increases water quantity consumption), } \\
\text { - more females in family (reduces employment opportunities and hence } \\
\text { will stay at home to look after daily chorus at the home including } \\
\text { collection of water), } \\
\text { - low annual income level (a combination of above factors). }\end{array}$ \\
\hline 2 & $\begin{array}{l}\text { Product Service } \\
\text { (Technical) Quality }\end{array}$ & $\begin{array}{c}\mathrm{H} 2 \\
\text { (Negative) }\end{array}$ & $\begin{array}{l}\text { Sole dependence on public water service provider (monopoly) reduces } \\
\text { User satisfaction since this attribute specifically measures the pressure } \\
\text { of water supply from the provider }\end{array}$ \\
\hline 3 & $\begin{array}{l}\text { Service Quality } \\
\text { attributes: (a sort of } \\
\text { provider efficiency) }\end{array}$ & $\begin{array}{c}\mathrm{H} 3 \\
\text { (Positive) }\end{array}$ & $\begin{array}{l}\text { Lower the service quality (such as connection/disconnection of water } \\
\text { supply, tariff structure, billing accuracy by the provider), lower the User } \\
\text { satisfaction }\end{array}$ \\
\hline 4 & $\begin{array}{l}\text { Customer } \\
\text { Satisfaction \& } \\
\text { Provider's }\end{array}$ & $\begin{array}{c}\mathrm{H} 4 \\
\text { (Positive) }\end{array}$ & $\begin{array}{l}\text { More service alternates if available leads to higher User satisfaction } \\
\text { due to substitute effect }\end{array}$ \\
\hline & $\begin{array}{l}\text { complaints } \\
\text { handling process } \\
\text { attributes }\end{array}$ & $\begin{array}{c}\mathrm{H} 5 \\
\text { (Negative) }\end{array}$ & $\begin{array}{l}\text { If alternates breakdown frequently lower the User satisfaction (as it } \\
\text { aggravates substitutability effect) }\end{array}$ \\
\hline 5 & $\begin{array}{l}\text { Process Attributes } \\
\text { - Customer Voice: }\end{array}$ & $\begin{array}{c}\mathrm{H} 6 \\
\text { (Positive) }\end{array}$ & $\begin{array}{l}\text { If the process of service availability is good, the User satisfaction is } \\
\text { high }\end{array}$ \\
\hline 6 & Customer Loyalty: & $\begin{array}{c}\mathrm{H} 7 \\
\text { (Positive) }\end{array}$ & $\begin{array}{l}\text { If service attribute experienced by the User is good, the User derives } \\
\text { higher satisfaction }\end{array}$ \\
\hline
\end{tabular}

Table 4.2. List of Variables used in the Model Estimation

\begin{tabular}{|c|c|c|}
\hline Category & Variable code & VARIABLE Description (Units of metric) \\
\hline $\begin{array}{l}\text { Demography/O } \\
\text { ccupant factors }\end{array}$ & FLOOR & $\begin{array}{l}\text { House - Number of floors. Living status of the users, whether the user stays in } \\
\text { house with } 1 \text { floor, or } 2 \text { floors or } 3 \text { floors..... Coded as Ground-2; Ground + first } \\
-3 \text {; Ground + two }-4 \text {; Multi-storied }-5 \text { ). } \\
\text { Family size }\end{array}$ \\
\hline \multirow[t]{2}{*}{ Usage pattern } & SOURCE & $\begin{array}{l}\text { Main source of water used }(1 / \ldots \ldots .8) \text { Coded as tap at home coded as } 1 \text {, public } \\
\text { tap coded as } 2, \ldots \ldots, \text { tanker supply (free of cost coded as } 6 \text { and tanker supply } \\
\text { with cost coded as } 7\end{array}$ \\
\hline & FWS & $\begin{array}{l}\text { Frequency of water supply coded as } 1 \text {-every day; } 2 \text {-once in } 2 \text { days; } 3 \text {-once in } 3 \\
\text { days; } 4 \text {-once in } 4-5 \text { days; } 5 \text {-irregular supply }\end{array}$ \\
\hline \multirow{2}{*}{$\begin{array}{l}\text { Product Service } \\
\text { quality } \\
\text { (Technical } \\
\text { attribute) }\end{array}$} & DWS & $\begin{array}{l}\text { Duration of water supply in terms of number of hours' water supply available for } \\
\text { the User on the day of supply (coded as } 1 \text { - less than an hour; } 2 \text {-one to two } \\
\text { hours; } 3 \text {-two to three hours; } 4 \text {-three to five hours; } 5 \text {-more than } 5 \text { hours). }\end{array}$ \\
\hline & WP & 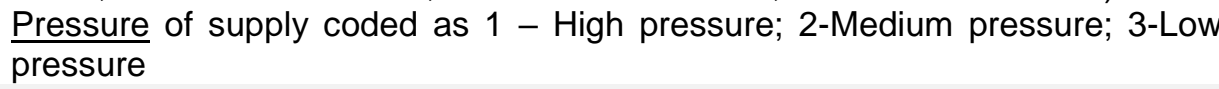 \\
\hline \multirow{4}{*}{$\begin{array}{l}\text { Coping strategy } \\
\text { - Physical } \\
\text { service attribute }\end{array}$} & COPING & $\begin{array}{l}\text { Coping strategy coping Yes/No. Purchase from outside coded as 1, borrow from } \\
\text { neighbours coded as 2, and others coded as } 3 \text { ) }\end{array}$ \\
\hline & AWS & $\begin{array}{l}\text { Alternative water supply (provision of bore water). Frequency of bore well water } \\
\text { supplied (substitute). Coded as } 1 \text { - daily; } 2 \text {-once in } 2 \text { days; } 3 \text {-once a week; } 4- \\
\text { do not receive }\end{array}$ \\
\hline & WM & Water meter - monthly bill-payment \\
\hline & TARIF & $\begin{array}{l}\text { Water meter - impression tariff. High tariff coded as } 1 \text {, just right } 2 \text {, and low coded } \\
\text { as } 0 \text { ) }\end{array}$ \\
\hline $\begin{array}{l}\text { Process } \\
\text { Attributes }\end{array}$ & DOCUMENT & Were you able to produce all necessary documents easily? (1/2) \\
\hline \multirow{2}{*}{$\begin{array}{l}\text { Service } \\
\text { attribute- }\end{array}$} & ANS & $\begin{array}{l}\text { tion - irregular supply through advance notification to user coded } \\
\text { ometimes - } 2 \text {; never-3) }\end{array}$ \\
\hline & RESOLUT & oblem resolution - problem - BWSSB \\
\hline
\end{tabular}


Complaints INT resolution
Are you aware of any customer interaction meetings held by BWSSB in various technology platform for creating awareness of BWSSB services coded as yes1; no-2; I don't know -3.

\subsubsection{Services Quality}

More than half the consumers receive water once in two days, followed by those getting it once in three days. On the days of water supply, less than half receive it for 2-3 hours while one-fifth receive it for 1-2 hours.

Water was mainly received between $7 \mathrm{am}$ and 12 noon (61\% Users). Majority of the consumers $(85 \%)$ found the water to be adequate; coping through BWSSB provided bore well water (10\% Users), along with purchase of water, and additional use of public taps.

Regarding Pressure of water supply: $61 \%$ consumers reported medium.: $84.6 \%$ consumers receiving daily water supply were satisfied with adequacy of water supplied. One-fourth each of the consumers expressed that the color of water was muddy and was having odor. $82 \%$ reported that the water supplied by BWSSB was sweet in taste.

Breakdown in water supply: reported by $20 \%$ consumers, reasons included leakage in the pipe line, bursting of water pipe and diversion of water from the main line.

Satisfaction with quality and quantity of water: $68 \%$ expressed complete satisfaction, while $24 \%$ expressed partial satisfaction. With regard to overall satisfaction of water services, $81 \%$ were completely satisfied, $18 \%$ partially satisfied and $1 \%$ dissatisfied.

\subsubsection{Other User Experiences}

About $96 \%$ did not have Rain water harvesting (RWH). Those who have the RWH system had to spend an average of INR 11,121/- per unit. Nearly $20 \%$ consumers reported problems with manholes. $10 \%$ Users noticed leakage in the pipeline near their house. Among those who noticed leakage, $68 \%$ brought it to the notice of the BWSSB authorities. $72 \%$ reported action taken by the BWSSB to stop leakage, $22 \%$ consumers reported water theft. $22 \%$ consumers reported irregularity in water supply sometimes, 39\% reported lack of advance notice in irregular water supply.

\section{MVC MODEL RESULTS AND DISCUSSION}

We run multivariate choice (MVC) system model jointly to check the robustness of the model results relative to traditional logit specification. In these models, satisfied and highly satisfied Users are coded as 1 and dissatisfied Users as 0 . Probability is expressed as probability of satisfaction (1) relative to dissatisfaction (0) across dimensions of quality, quantity and overall satisfaction of Users. Using Variance inflation factor (VIF) as diagnostic tool, all regressors with VIF $>10$ which signify multi-collinearity are dropped from the model estimation.

\subsection{Discussion of MVC Model Results}

Table 5.1 shows the results of MVC. Demographic/occupant variables: number of Floor and FAMILY SIZE are found to be significant for explaining User's quality and quantity satisfaction. As they have no meaning when considered standalone, they have been treated as interacting variables with various dimensions of attributes (Omonona, 2009).

Duration of water supply (DWS) has no impact on any of the three $\left(Y_{1}, Y_{2}\right.$, and $\left.Y_{3}\right)$ equations. But when considered with FAMILY SIZE, the joint variable is found to be positive and significant at $10 \%$ error level to explain quality satisfaction of Users but not quantity and overall satisfaction. This implies that large family size when they have long duration of water supply, are qualitatively satisfied. The marginal effect is $0.0838 \%$.

With regard to the sources of water (SOURCE) which the Users access, the relationship was not significant in all three equations. But when combined with demography/occupant variable of number of floors (FLOOR) the relationship was negative and significant at 5\% error level in Quantity equation (and not in quality and overall equations). This implies that Users residing in low floors were not satisfied with the alternative sources of water as it involved cost. The marginal effect is $-0.145 \%$.

Frequency of water supply (FWS) is a service quality dimension variable. This variable has negative sign and is not statistically significant across $Y_{1}, Y_{2}$, and $Y_{3}$ equations jointly. This variable when combined with the floor occupancy, the interaction variable is found to be positive and significant at $10 \%$ error level in equation $Y_{1}$ and 
$5 \%$ error level in $Y_{2}$ equation but not in $Y_{3}$ equation. This implies that Users staying at lower level of their house and having regular water supply are satisfied both with quality and quantity. This variable together with family size has negative sign in $Y_{1}$ equation and not in $Y_{2}$ and $Y_{3}$ equations signifying that Users with large family size are not satisfied with quantity if the frequency of water supply is irregular which is plausible. The marginal effect is $0.196 \%$.

Table 5.1. Summary of Statistically Significant Factors Discriminating Various Dimensions of User Quality, Quantity and Overall Joint Satisfactions as a System

\begin{tabular}{|c|c|c|c|c|}
\hline \multirow{3}{*}{ Variable description } & \multirow{3}{*}{$\begin{array}{l}\text { Linkage to } \\
\text { Hypotheses }(\mathrm{H})\end{array}$} & \multicolumn{3}{|c|}{ MULTI VARIATE CHOICE (MVC) } \\
\hline & & $\begin{array}{c}\text { Quality } \\
\text { Saticfactinn }\end{array}$ & $\begin{array}{l}\text { Quantity } \\
\text { Saticfaction }\end{array}$ & $\begin{array}{l}\text { Overall } \\
\text { Satisfaction }\left(\mathrm{Y}_{2}\right)\end{array}$ \\
\hline & & \multicolumn{3}{|c|}{ Probability of $Y_{i}$ conditional on $Y_{j}$, for $i j=1,2,3$} \\
\hline \multicolumn{2}{|c|}{ Demographic/Occupant factors } & \multicolumn{3}{|c|}{ Marginal Effect } \\
\hline FLOOR & $\mathrm{H}_{1}$ & $0.173^{* *}$ & $0.218^{\star * *}$ & $0.310^{\star *}$ \\
\hline FAMILY SIZE & $\mathrm{H}_{1}$ & $-0.0867^{* *}$ & $-0.103^{* * *}$ & 0.0466 \\
\hline \multicolumn{5}{|c|}{ Usage Pattern \& Service Attributes } \\
\hline MAIN SOURCE & $\mathrm{H}_{2}$ & 0.0325 & 0.0450 & -0.434 \\
\hline FWS & $\mathrm{H}_{3}$ & -0.387 & -0.212 & -0.681 \\
\hline DWS & $\mathrm{H}_{3}$ & -0.214 & -0.175 & -0.0912 \\
\hline \multicolumn{5}{|c|}{ Process \& Coping Strategy Attributes } \\
\hline WP & $\mathrm{H}_{3}$ & -0.340 & -0.197 & -0.986 \\
\hline COPING & $\mathrm{H}_{3}$ & -0.368 & 0.120 & 1.196 \\
\hline AWS & $\mathrm{H}_{4}$ & 0.379 & $0.529^{* *}$ & -0.520 \\
\hline DOCUMENTS & $\mathrm{H}_{6}$ & -0.00430 & $-1.188^{\star *}$ & 4.364 \\
\hline \multicolumn{5}{|c|}{ Water - Complaints \& Resolutions } \\
\hline WM-MBP & $\mathrm{H}_{7}$ & 0.0974 & -0.148 & -0.178 \\
\hline TARIF & $\mathrm{H}_{7}$ & 0.209 & $-0.724^{* *}$ & 0.442 \\
\hline ANS & $\mathrm{H}_{7}$ & $-0.664^{*}$ & 0.0214 & 0.717 \\
\hline RESOLUT & $\mathrm{H}_{7}$ & $0.359^{*}$ & 0.313 & $0.689^{*}$ \\
\hline INT & $\mathrm{H}_{7}$ & $0.713^{* *}$ & 0.180 & 0.390 \\
\hline \multicolumn{5}{|c|}{ Interaction of Demographic/Occupant factors with other attributes } \\
\hline FLOOR*MAIN SOURCE & $\mathrm{H}_{1} \& \mathrm{H}_{2}$ & 0.161 & $-0.145^{\star \star}$ & 0.362 \\
\hline FLOOR*FWS & $\mathrm{H}_{1} \& \mathrm{H}_{3}$ & $0.165^{\star}$ & $0.210^{\star *}$ & -0.0212 \\
\hline FLOOR*DWS & $\mathrm{H}_{1} \& \mathrm{H}_{3}$ & 0.0445 & $0.135^{\star \star}$ & 0.283 \\
\hline FLOOR ${ }^{*}$ TARIF & $\mathrm{H}_{1} \& \mathrm{H}_{7}$ & 0.0275 & $0.371^{* * *}$ & -0.0353 \\
\hline FLOOR ${ }^{\star} I N T$ & $\mathrm{H}_{1} \& \mathrm{H}_{7}$ & -0.158 & $-0.241^{\star *}$ & -0.191 \\
\hline FAMILY SIZE*FWS & $\mathrm{H}_{1} \& \mathrm{H}_{3}$ & $-0.196^{\star *}$ & -0.0534 & 0.232 \\
\hline FAMILY SIZE*DWS & $\mathrm{H}_{1} \& \mathrm{H}_{3}$ & $0.0838^{*}$ & 0.0397 & -0.0225 \\
\hline FAMILY SIZE*WP & $\mathrm{H}_{1} \& \mathrm{H}_{3}$ & -0.0186 & -0.0458 & $0.430^{\star *}$ \\
\hline FAMILY SIZE*COPING & $\mathrm{H}_{1} \& \mathrm{H}_{3}$ & -0.140 & -0.150 & $-0.671^{\star *}$ \\
\hline FAMILY SIZE*AWS & $\mathrm{H}_{1} \& \mathrm{H}_{4}$ & -0.0821 & $-0.189^{* * *}$ & -0.359 \\
\hline FAMILY SIZE*WM-MBP & $\mathrm{H}_{1} \& \mathrm{H}_{7}$ & 0.0640 & $0.0881^{*}$ & 0.0250 \\
\hline
\end{tabular}

"NStatistical significance at $\alpha=0.001$; " Statistical significance at $\alpha=0.01$ to 0.03 ; " Statistical significance at $\alpha=0.05$.

Duration of water supply (DWS) is a service quality dimension variable in terms of number of hours' water supply available for the User. This variable has negative sign and is not statistically significant across all 3 equations. However, this variable when combined with the User's occupancy status (FLOOR) as an interaction variable, is found to be positive and significant at $5 \%$ error level in equation $Y_{2}$ (and not in equations $Y_{1}$ and $Y_{3}$ ). This implies that Users at the low FLOOR (like ground floor and first floor) when they have long duration of water supply, they are satisfied quantity-wise. The marginal effect is $0.135 \%$.

Pressure of water supply from provider (WP) is a coping strategy variable. This variable has negative sign and is statistically not significant across all three equations. This variable when combined with FAMILY SIZE as an interaction variable, is found to be positive and significant at $5 \%$ error level in equation $\mathrm{Y}_{3}$. This implies that Users with large FAMILY SIZE when they experience high pressure of water supply are totally satisfied which is plausible. The marginal effect is $0.43 \%$. 
As to the question of how Users cope up with daily water requirement (COPING), the variable had no significant impact in all the 3 equations. But when combined with FAMILY SIZE variable, the relation was negative and significant at $5 \%$ level in equation 3 . This implies that particularly Users with large FAMILY SIZE were totally not satisfied if they have to purchase from outside or borrow from neighbours to cope when the service provider did not supply water regularly. The marginal effect is $0.671 \%$.

Availability of alternative water (AWS) through bore water supply from provider is a service quality dimension coping strategy variable. This variable has positive sign and is statistically significant at $5 \%$ error level in $Y_{2}$ equation but not in $Y_{1}$ and $Y_{3}$ equations. This implies that, Users are satisfied with the quantity if the alternative water supply is regular. This variable when combined with FAMILY SIZE as an interaction variable, is found to be negative but highly significant at less than $1 \%$ error level. This implies that Users with large family size are highly dissatisfied with the quantity of alternative supply provided through bore well. The marginal effect shows that if the bore water supply improves from irregular to daily, these User's quality satisfaction improves by $0.189 \%$.

As to the process attribute question, were the Users able to access necessary documents easily to get service connection (DOCUMENT), the relation was negative and significant at $5 \%$ error level. This implies that the documentation was probably not easier to process water service connection and hence users were not satisfied. This suggests the need for the service provider to simplify documents and making it easy for compliance by the Users for obtaining service connections.

With regard to User impression of monthly periodicity of water bill payment (WM-MBP), there was no significant impact on the User's satisfaction across all three equations. However, interaction of this variable with FAMILY SIZE variable, there was significant positive relation only in $Y_{2}$ equation. This implies that users with large FAMILY SIZE were generally satisfied with monthly periodicity of water bills. The marginal effect is $0.0881 \%$. Similarly, with regard to impression of Users on magnitude of tariff charged for the water services there was negative and significant relationship with $Y_{2}$. This implies that Users satisfaction generally increased if the tariff is reduced. When combined with demographic variable number of floors (FLLOR), the relationship was positive across all three equations. It was highly significant at error level less than $1 \%$ in equation $Y_{2}$. This signifies that Users residing in low level floors were highly satisfied with magnitude of tariff charged by the service provider. The marginal effect is $0.371 \%$.

Prior notification from the supplier (ANS) is less significant with negative sign for User quality satisfaction. This implies that if the Users are well informed in advance about the irregular supply, User's probability of quality satisfaction increases, the marginal effect being $-0.664 \%$.

With regard to problem resolution (RESOLUT) the relationship was positive and less significant at $10 \%$ error level in equation 1 and 3 . This means that Users generally were overall satisfied with the way problems were handled on quality attributes by service provider.

With regard to customer interaction meetings arranged by the service provider with Users, the sign of relationship with User quality satisfaction was positive and significant at $5 \%$ error level. Together with demographic variable number of floors of the house (FLOOR), the Users staying in low level floors were satisfied with customer interaction meetings although they were not overall satisfied. This implies more such meetings from the service provider help Users staying in low level floors to become aware of the processes in making alternative arrangements in case of emergency of non-supply or interruptions if any. (how about those in higher floors?)

\subsection{Model Diagnostics}

Table 5.2 summarizes the model diagnostics of the joint system MVC evaluated so far. MVC model correctly predicted $85.4 \%$ of the times the overall satisfaction of Users to the services provided by BWSSB. High significance of Wald test imply that the joint model specification of MVC was superior to single equation logit specification. Further, considering the statistical significance of cross equation error correlation $\rho$ in the MVC (across three equations), the results of joint estimation (as in Table 5.1 and Table 5.2) appears to be robust and superior compared to traditional single equation logit specification used in earlier studies.

Table 5.2. Summary of MVC Model Diagnostics 


\begin{tabular}{|c|c|c|c|}
\hline Log Likelihood & \multicolumn{3}{|c|}{ Log likelihood $=-868.28077^{\star \star \star}$} \\
\hline LR $x^{2}$ (chi square) & \multicolumn{3}{|c|}{ Wald $X^{2}(135)=382.58^{* * *}$} \\
\hline Probability $x^{2}$ & \multicolumn{3}{|c|}{0.00000} \\
\hline Number of Observations & \multicolumn{3}{|l|}{1944} \\
\hline AIC & \multicolumn{3}{|l|}{2018.57} \\
\hline $\mathrm{BIC}$ & \multicolumn{3}{|l|}{2804.28} \\
\hline Correct Classification (1) & \multicolumn{3}{|l|}{$85.4 \%$} \\
\hline Correct Classification (0) & \multicolumn{3}{|c|}{$\begin{array}{l}2.02 \%(12.58 \% \text { classification belong to } 6 \text { other categories } \\
\text { of } 1 \& 0 \text { ) which is unique to Multivariate probability } \\
\text { prediction }\end{array}$} \\
\hline $\begin{array}{l}\text { Equations } \rightarrow \\
\quad(\text { Cross equation } 1 \& 2) \rho \varepsilon_{12}\end{array}$ & $Y_{1}$ & $\begin{array}{c}Y_{2} \\
0.28404^{* * *}\end{array}$ & $\begin{array}{c}Y_{3} \\
0.226846^{*}\end{array}$ \\
\hline (Cross equation $1 \& 3$ ) $\rho \varepsilon_{13}$ & $0.28404^{* * *}$ & & $0.754642^{* * *}$ \\
\hline (Cross equation $2 \& 3$ ) $\rho \varepsilon_{23}$ & $0.226846^{*}$ & $0.754642^{\star \star *}$ & \\
\hline
\end{tabular}

Likelihood ratio test of $\rho \varepsilon_{12}=\rho \varepsilon_{13}=\rho \varepsilon_{23}=0: x 2(3)=42.3216$ Prob $>x^{2}=0.0000$

\subsection{Neural Network Implementation with PAC data}

As discussed in section 1, the problem of predicting the users' responses is a pattern recognition problem where a neural network (NN) could classify inputs into a set of target categories. The procedure for using NN is select data, create and train a network, and evaluate its performance using cross-entropy matrices. A two-layer feed-forward network, with hyperbolic-tangent hidden layer and softmax output neurons can classify PAC data vectors arbitrarily well, given enough neurons in its hidden layer. In our experiments, the number of hidden layer that gave best performance is 6 neurons (Figure 5.1).

Figure 5.1. Feed Forward Neural Network with 26 inputs, 6 hidden neurons, and 3 outputs

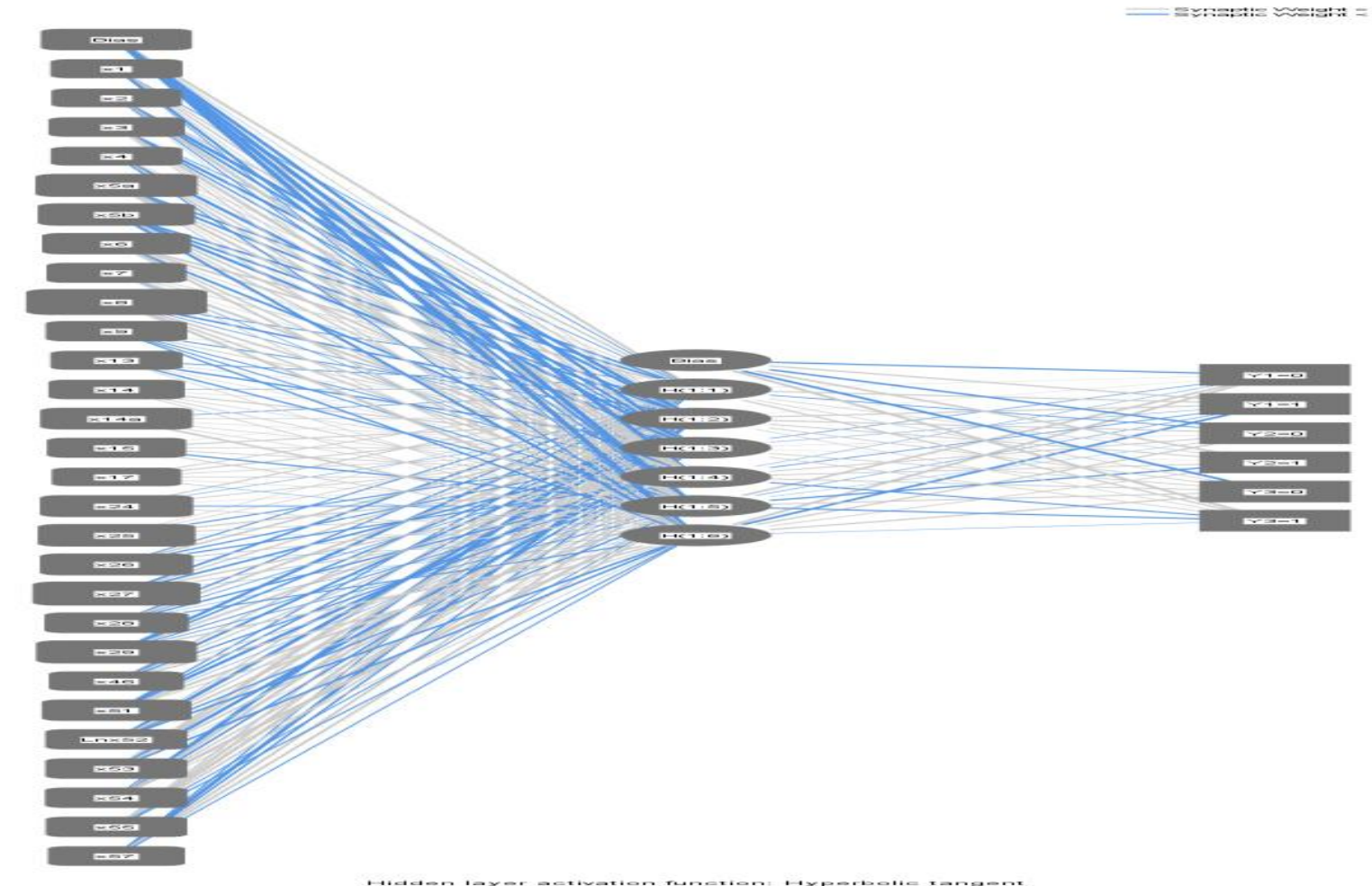

Network Information in Figure $\mathbf{5 . 1}$

\begin{tabular}{|c|c|c|}
\hline \multirow{3}{*}{ Input Layer } & Covariates & \\
\hline & Number of Units ${ }^{a}$ & 28 \\
\hline & Rescaling Method for Covariates & Standardized \\
\hline \multirow{3}{*}{ Hidden Layer(s) } & Number of Hidden Layers & 1 \\
\hline & Number of Units in Hidden Layer $1^{\mathrm{a}}$ & 6 \\
\hline & Activation Function & Hyperbolic tangent \\
\hline & 1 & Y1 \\
\hline
\end{tabular}


The neural network was trained with scaled conjugate gradient back propagation. We have used the same data of 1944 User observations that were used with the MVC model. and divided into three kinds of samples for the purpose of experimentations as in Table 5.3.

Table 5.3. Case Processing Summary

\begin{tabular}{llcc}
\hline & & N & Percent \\
\hline & Training & 1157 & $59.5 \%$ \\
Sample & Testing & 589 & $30.3 \%$ \\
& Holdout & 198 & $10.2 \%$ \\
Valid & & 1944 & $100.0 \%$ \\
Excluded & & 113 & \\
Total & & 2057 & \\
\hline
\end{tabular}

While $1157(59.5 \%)$ data samples have been assigned for the training phase, and the network is adjusted according to its error; 589 (30.3\%) data samples have been assigned for the testing phase. These have no effect on training and indicates an independent measure of network performance during and after training. About $198(10.2 \%)$ data samples have been assigned as hold out sample for the validation phase. These were used to measure network generalization, and to halt training when generalization stabilizes at a certain range.

The training is done using back propagation neural networks with 6 hidden neurons. It used Minimizing Cross-Entropy (CE) results in good classification. Lower values are better. Zero means no error. Table 5.4 displays the error classification across three equations.

Table 5.3. NN Model summary of error classification across 3 equations

\begin{tabular}{|c|c|c|}
\hline \multirow{3}{*}{ Training } & $\begin{array}{l}\text { Cross Entropy Error } \\
\text { Average Percent Incorrect Predictions }\end{array}$ & $\begin{array}{l}560.226 \\
5.3 \%\end{array}$ \\
\hline & $\begin{array}{ll}\text { Percent Incorrect Predictions } & \text { Y1 } \\
\text { for Categorical Dependents } & \text { Y2 } \\
\end{array}$ & $\begin{array}{l}7.1 \% \\
7.9 \% \\
1.0 \%\end{array}$ \\
\hline & $\begin{array}{l}\text { Stopping Rule Used } \\
\text { Training Time }\end{array}$ & $\begin{array}{l}1 \text { consecutive step(s) with no decrease in errora } \\
0: 00: 00.89\end{array}$ \\
\hline \multirow[b]{2}{*}{ Testing } & $\begin{array}{l}\text { Cross Entropy Error } \\
\text { Average Percent Incorrect Predictions }\end{array}$ & $\begin{array}{l}316.194 \\
6.5 \%\end{array}$ \\
\hline & $\begin{array}{ll}\text { Percent Incorrect Predictions } & \text { Y1 } \\
\text { for Categorical Dependents } & \text { Y2 }\end{array}$ & $\begin{array}{l}10.2 \% \\
8.7 \% \\
0.7 \%\end{array}$ \\
\hline Holdout & $\begin{array}{ll}\text { Average Percent Incorrect Predictions } \\
\text { Percent Incorrect Predictions } & \text { Y1 } \\
\text { for Categorical Dependents } & \text { Y2 } \\
& \text { Y3 }\end{array}$ & $\begin{array}{l}6.4 \% \\
9.1 \% \\
9.1 \% \\
1.0 \%\end{array}$ \\
\hline
\end{tabular}

${ }^{\mathrm{a} E r r o r}$ computations are based on the testing sample.

In training phase, the average percent incorrect prediction of errors in Users' quality satisfaction (equation $Y_{1}$ ) was $7.1 \%$, in Users' quantity satisfaction (equation $\mathrm{Y}_{2}$ ) it was $7.9 \%$ and in Users' overall satisfaction (equation $Y_{3}$ ) it was just $1 \%$.

Similarly, in testing phase, the average percent incorrect prediction of errors in Users' quality satisfaction (equation $\mathrm{Y}_{1}$ ) was $10.2 \%$, in Users' quantity satisfaction (equation $\mathrm{Y}_{2}$ ) it was $8.7 \%$ and in Users' overall satisfaction (equation $\mathrm{Y}_{3}$ ) it was just $0.7 \%$. 
In the validation phase, which is the important phase of $\mathrm{NN}$ model for prediction, the average percent incorrect prediction of errors in Users' quality satisfaction (equation $\mathrm{Y}_{1}$ ) was $9.1 \%$, in Users' quantity satisfaction (equation $\mathrm{Y}_{2}$ ) it was $9.1 \%$ and in Users' overall satisfaction (equation $\mathrm{Y}_{3}$ ) it was $1 \%$.

Tables $5.5(a$ and $b)$ display the correct classification across the three equations of Users' dimensions of quality, quantity and overall satisfaction. The NN model overall correctly predicted User responses $94.7 \%$ during training phase, $93.5 \%$ during testing phase and $93.6 \%$ during validation phase. The results reflect the excellent performance of the NN method over the MVC model. The NN model parameters are shown in Appendix-1 which has similar interpretation as in MCV model and can be used for prediction purposes for any policy changes proposed by the service provider in the case.

Table 5.5. (a) Prediction of $Y_{1}, Y_{2}, Y_{3}$.

\begin{tabular}{l|c|c|c|c|c|c|c|c|c|c}
\hline \multirow{2}{*}{ Sample } & \multirow{2}{*}{ Observed } & \multicolumn{3}{|c|}{ Predicted $\mathbf{Y}_{\mathbf{1}}$} & \multicolumn{3}{c|}{ Predicted $\mathbf{Y}_{\mathbf{2}}$} & \multicolumn{3}{c}{ Predicted $\mathbf{Y}_{\mathbf{3}}$} \\
\cline { 3 - 11 } & & 0 & 1 & $\%$ Correct & 0 & 1 & $\%$ Correct & 0 & 1 & $\%$ Correct \\
\hline \multirow{3}{*}{ Training } & 0 & 40 & 50 & $44.4 \%$ & 0 & 91 & $0.0 \%$ & 0 & 11 & $0 \%$ \\
& 1 & 32 & 1035 & $97 \%$ & 0 & 1066 & $100 \%$ & 0 & 1146 & $100 \%$ \\
& Overall \% & $6.2 \%$ & $93.8 \%$ & $92.9 \%$ & $0 \%$ & $100 \%$ & $92.1 \%$ & $0 \%$ & $100 \%$ & $99 \%$ \\
\multirow{5}{*}{ Testing } & 0 & 13 & 33 & $28.3 \%$ & 0 & 51 & $0 \%$ & 0 & 4 & $0.0 \%$ \\
& 1 & 27 & 516 & $95.0 \%$ & 0 & 538 & $100 \%$ & 0 & 585 & $100 \%$ \\
& Overall \% & $6.8 \%$ & $93.2 \%$ & $89.8 \%$ & $0 \%$ & $100 \%$ & $91.3 \%$ & $0.0 \%$ & $100 \%$ & $99.3 \%$ \\
\multirow{5}{*}{ Holdout } & 0 & 8 & 10 & $44.4 \%$ & 0 & 18 & $0 \%$ & 0 & 2 & $0.0 \%$ \\
& 1 & 8 & 172 & $95.6 \%$ & 0 & 180 & $100 \%$ & 0 & 196 & $100 \%$ \\
& Overall \% & $8.1 \%$ & $91.9 \%$ & $90.9 \%$ & $0 \%$ & $100 \%$ & $90.9 \%$ & $0 \%$ & $100 \%$ & $99 \%$ \\
\hline
\end{tabular}

Table 5.5 (b). Overall Percent Correct

\begin{tabular}{lc}
\hline Sample & Overall Percent Correct \\
\hline Training & $94.7 \%$ \\
Testing & $93.5 \%$ \\
Holdout (Validation) & $93.6 \%$ \\
\hline
\end{tabular}

Table 5.6 and Figure 5.2 shows the importance of factors in NN model in the order of decreasing importance for explaining the User behaviour. Some of these variables were insignificant in MVC model.

Table 5.6. Independent Variable Importance

\begin{tabular}{llcc}
\hline Code & Variable details & Importance & $\begin{array}{c}\text { Normalized } \\
\text { Importance }\end{array}$ \\
\hline x8 & Frequency of water supply & 0.088 & $100 \%$ \\
x29 & Documentation follow-up visits & 0.058 & $66.2 \%$ \\
x24 & Water connection info & 0.047 & $53.1 \%$ \\
x51 & Water meter bill accuracy & 0.042 & $47.4 \%$ \\
x54 & Advance notification of supply -Problem resolution & 0.032 & $36.0 \%$ \\
x9 & Duration of water supply & 0.030 & $34.0 \%$ \\
x15 & Alternative water supply through bore & 0.026 & $29.7 \%$ \\
x14 & Coping strategy & 0.022 & $25 \%$ \\
x13 & How often the User would like to get the service & 0.016 & $18.1 \%$ \\
x17 & Breakdowns experienced in bore water supply & 0.012 & $13.8 \%$ \\
\hline
\end{tabular}

Figure 5.2. Independent Variable Importance 


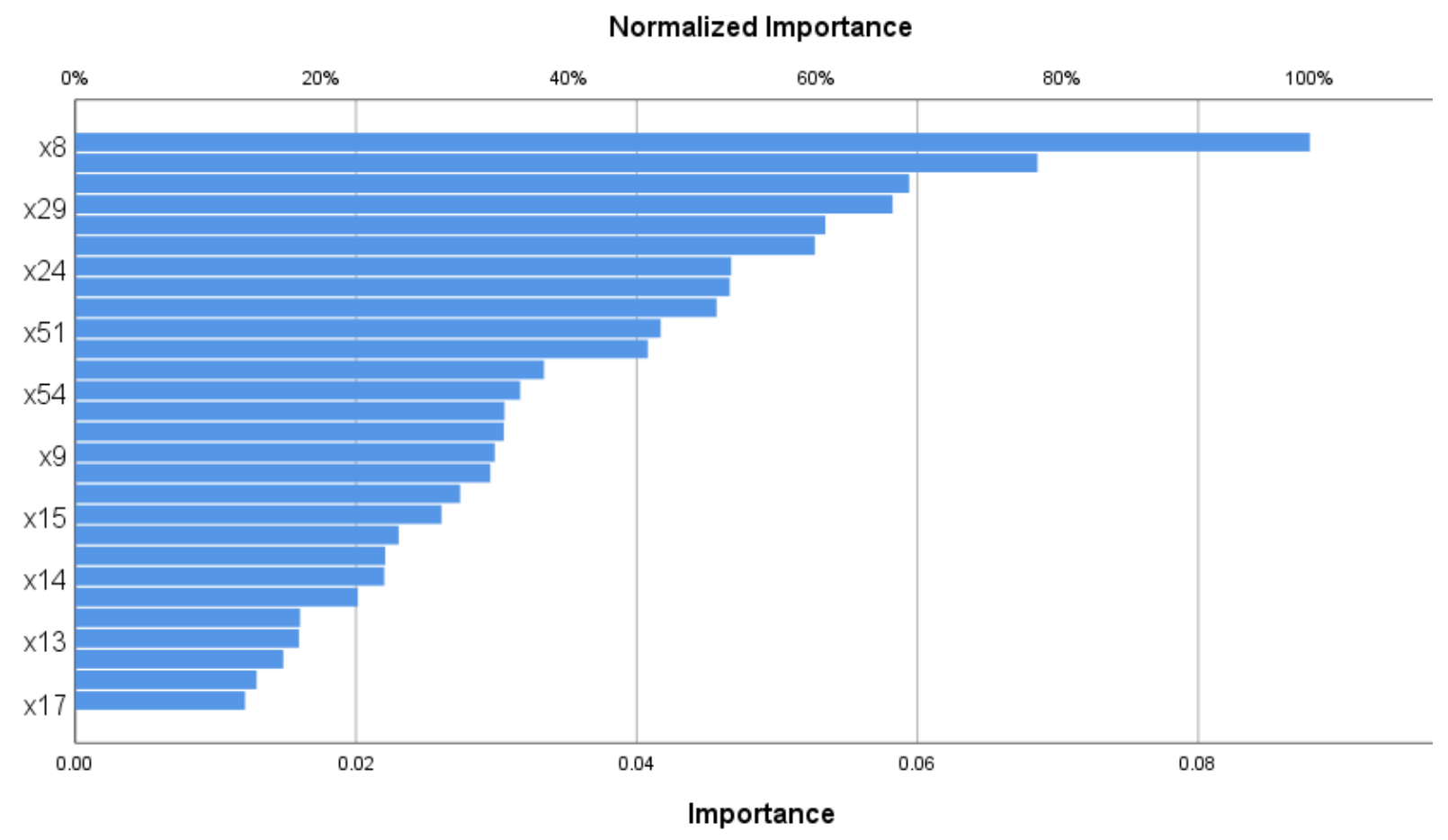

\section{STUDY CONCLUSIONS, LIMITATIONS AND FUTURE DIRECTIONS}

\subsection{Conclusions}

The research objectives were to Develop a multivariate choice (MVC) system and neural network (NN) framework to predict users' responses; and Identify factors that determine quality, quantity and overall User satisfaction of services of public water utility as a case study. Seven sets of hypotheses were formulated and tested. Wald test confirm that there exits cross equation correlation across quality, quantity and overall Users' satisfaction dimensions. Based on the system model, the study concludes as below:

User quality satisfaction is significantly and positively influenced by: Alternative water supply (provision of bore water); Service provider support in problem resolution for the Users; Interaction meetings arranged by the service provider with Users; User residence with low floors with higher frequency of water supply; Large family size with longer duration of water supply and with monthly bill payment. All these attributes enable Users to develop loyalty to the service provider due to high degree of quality satisfaction.

User quality satisfaction is significantly and negatively influenced by: Absence of prior notification by service provider about supply interruptions; Large family size experiencing irregular frequency of water supply. These attributes create anxiety and provides opportunity to Users to voice their quality dissatisfaction of service provider.

User quantity satisfaction is significantly and positively influenced by: Service provider support in problem resolution for the Users; Interaction meetings arranged by the service provider with Users; Residing at lower levels in their house and having supplies with higher frequency; and Large family size experiencing supplies with increased duration. All these attributes enable Users to develop loyalty to the service provider due to high degree of quantity satisfaction.

User quantity satisfaction is significantly and negatively influenced by: Non-easy documentation for service connection; Unfavourable impression of Users on meter tariff; Large family size experiencing irregular infrequent supplies; Higher number of floors coupled with alternate water sources which require cost; Higher number of floors coupled with less interaction meetings with the service provider; and Large family size experiencing the alternate bore water supplies which entail cost. All these attributes forces Users to voice their displeasure on quantity supplied by the service provider.

User overall satisfaction is significantly and positively influenced by: Ease with which service provider solves the problem of the User; and Large family size experiencing high pressure of water supplies. All these attributes enable Users to develop loyalty to the service provider due to high degree of overall satisfaction. 
User overall satisfaction is significantly and negatively influenced by Large family size experiencing alternate supply of bore which entail cost to cope with their daily requirement.

Due to its superiority of no assumptions on functional forms, hypothesis and error assumptions, Neural network (NN) was specified as an alternative to MCV econometric specification. The NN model overall correctly predicted User responses $94.7 \%$ during training phase, $93.5 \%$ during testing phase and $93.6 \%$ during validation phase. The results reflect the excellent performance of the NN method over the MVC model where the overall prediction of User response was $85.4 \%$. Further, NN model predicted factors such as Frequency of water supply; Documentation follow-up visits by Users; Water connection info; Water meter bill accuracy; Advance notification of supply for Problem resolution; Duration of water supply; Alternative water supply through bore; Coping strategy; How often the User would like to get the service and Breakdowns experienced in bore water supply as specific factors in the decreasing order of importance to predict the User Satisfaction of services provided by service provider.

\subsection{Policy Implications}

It is prudent for the service provider to take note of the voice attributes summarised above and take corrective steps to continuously improve these features so that Users are satisfied both by quality, quantity and overall satisfaction of the service provided. The policy initiatives in this regard help in developing Users' loyalty to the service provider.

\subsection{Limitation\& Future Directions}

The study used one period data which limits the analysis of Users' behaviour which is a limitation. The suggested MCV model and NN frameworks prove to be of potential tools for future research of User responses in predicting services provided both by public and private sector settings in UAE and Middle East region for Policy initiatives so that the service providers could improve their service delivery.

\section{REFERENCES}

Adamowski, J.F. (2008). Peak daily water demand forecast modeling using artificial neural networks. Journal of Water Resources Planning and Management, 134 (2), 119-128.

Andreassen, T.W. and Lindestad, B. (1998). The Impact of Corporate Image in the Formation of Customer Loyalty, Journal of Service Research, 1 (1).

Annoni, P., and R. Brüggemann (2009). Exploring Partial Order of European Countries, Social Indicators Research, 92: 471-487.

Bacchiocchi, E., M. Florio, and M. Gambaro (2011). Telecom Reforms in the EU: Prices and Consumers' Satisfaction, Telecommunications Policy, 35: 382-396.

Baker, B. and Tremolet, S. (2003). Regulation of Quality: Let competing Firms Offer a Mix of Price and Quality Options, The WorldBank, Washington, DC.

Beresteanu, A. (2003). Nonparametric Estimation of Regression Functions under Restrictions on Partial Derivatives. Working Paper, Department of Economics, Duke University. http://www.econ.duke.edu/ arie/shape.pdf.

Brudney, J.R. and England, R.E. (1982). Urban Policy Making and Subjective Service Evaluations: Are They Compatible? Public Administration Review, 42, pp.127-35.

Bougadis, J., Adamowski, K., Diduch, R. (2005). Short-term municipal water demand forecasting. Hydrological Processes, 19 (1), 137-148.

Cameron, A. C., and P. K. Trivedi (2005). Microeconometrics, Methods and Applications. Cambridge: Cambridge University Press.

Clarke, R.G. and Wallsten, S. (2003). Universal Service: Empirical Evidence on the Provision of Infrastructure to Rural and Poor Urban Consumers. In: BROOK P.J. AND IRWIN, T.C., ed, Infrastructure for Poor People: Public Policy for Private Provision. Washington, D.C.: World Bank, pp. 21-76. 
Clifton, J., and D. D. Díaz-Fuentes (2010). Evaluating EU Policies on Public Services: A Citizens' Perspective. Annals of Public and Cooperative Economics, 81 (2): 281-311.

Conway, P., and G. Nicoletti (2006). Product Market Regulation in Non-Manufacturing Sectors.

Cronin, J.J. and Taylor, S.A. (1992). Measuring Service Quality: A Reexamination and Extension. Journal of Marketing, 56, 56-68.

Das, B., Chan, E.K., Visoth, C., Pangare, G. and Simpson, R. (2010). Sharing the Reform Process: Learning from the Phnom Penh Water Supply Authority(PPWSA). Gland, Switzerland: IUCN.

Ferrari, P. A., P. Annoni, and G. Manzi (2010). Evaluation and Comparison of European Countries: Public Opinion on Services, Quality \& Quantity 44: 1191-1205.

Ferrari, P. A., and A. Barbiero (2011). Nonlinear Principal Component Analysis. In Modern Analysis of Customer Surveys: With Applications Using R, edited by R. S. Kenett and S. Salini, 333-356. Chichester: Wiley.

Fiorio, C. V., and M. Florio (2011). Would You Say That the Price You Pay for Electricity is Fair? Consumers' Satisfaction and Utility Reforms in the EU15. Energy Economics 33: 178-187.

Fiorio, C. V., M. Florio, S. Salini, and P. A. Ferrari (2007). European Consumers' Attitudes on Services of General Interest: Accessibility, Price and Quality. Working Paper 2007-04. Milan: DEAS, University of Milan.

Gershuny, J., Bittman, M. and Brice, J. (2005). Exit, Voice and suffering: Do Couples Adapt to Changing Employment Pattern? Journal of Marriage and family,67, pp. 656-65.

Gifi, A. (1990). Nonlinear Multivariate Analysis. New York: Wiley.

Hall, D. (2006). Water and Electricity in Nigeria. Public Service International Research Unit (PSIRU).

Hirschman, A. O. (1970). Exit, Voice and Loyalty. Responses to Decline in Firms, Organizations, and States. Cambridge, MA: Harvard University Press.

Hirschman, A.O. (1978). Exit, Voice and the State. World Politics, 31, pp. 90-107.

IUCN (2010). Sharing the Reform Process, Learning from the Phnom Penh Water Supply Authority. International Union for Conservation of Nature and Natural Resources, Bangkok, Thailand.

Jain, A., Ormsbee, L. (2002). Short-term water demand forecast modeling techniques - conventional methods versus Al. Journal of the American Water Resources Association, 94 (7), 64-72.

Jain, A., Varshney, A., Joshi, U. (2001). Short-term water demand forecast modeling at IIT Kanpu using artificial neural networks. Water Resources Management, 15 (5), 299-321.

Jamison, M.A.; Berg, V.S. and Gasmi, F. and Tavara, J.I. (2004). Annotated Reading List for Body of Knowledge on the Regulation of Utility Infrastructure and Services. Florida, USA: Public Utility Research Centre, University of Florida.

Jilke, S., and S. Van De Walle (2013). Two Track Public Services? Citizens' Voice Behaviour towards Liberalized Services in the EU15. Public Management Review, 15 (4): 465-476.

Jöreskog, K. G. (1970). A General Method for Analysis of Covariance Structure. Biometrika 57 (2): 239-251.

Katz, E. (1997). The Itra-Household Economics of Voice and Exit. Feminist Economics, 3(25-46).

Kaufmann, L. and Lowry, M.N. (2002). Price Cap Regulation of Power Distribution. Madison: Pacific Economics Group. 
Khatri, K.B. AND Vairavamoorthy, K. (2007). Challenges for Urban Water Supply and Sanitation in the Developing Countries. Discussion Paper on Urbanization, Delft, Netherlands.

Kim, Y. and Kang, J. (1995). Consumer Perception of Shopping Costs and its Relationship with Retail Trends. Journal of Shopping Research Centre, 2(1), pp. 27-61.

Lowery, D., Hoogland DeHoog. R. and Lyons, W.E. (1992). Citizenship in the Empowered Locality: An Elaboration, A Critique and A Partial Test. Urban AffairsQuarterly, 28 (3), pp.69-103.

Manzi, G., and P. A. Ferrari (2014). Statistical Methods for Evaluating Satisfaction with Public Services. CIRIEC Working Paper. Liège: CIRIEC.

McIntosh, A.C. (2003). Asian Water Supplies, Reaching the Urban Poor. Asian Development Bank, IWA, London.

Meyrick Associates (2002). Electricity Service Quality Incentives Scoping Paper. Prepared for: Queensland Competition Authority, Australia.

Michailidis, G., and J. De Leeuw (1998). The Gifi System of Descriptive Multivariate Analysis. Statistical Science 13: 307-336.

MNI (2006). Accelerating Water Supply and Sanitation for the Urban Poor, East African Regional Conference.

Myers, R. and Lacey, R. (1996). Consumer Satisfaction, Performance and Accountability in the Public Sector. International Review of Administrative Science, 62 (3), pp.331-350.

Myhal, G.C., Kang, J. and Murphy, J.A. (2008). Retaining Customers through Relationship Quality: A Service Business Marketing Case. Journal of Services Marketing, 22(6), pp. 445-53.

O'Brien, R. M., and P. Homer (1987). Corrections for Coarsely Categorized Measures: LISREL's OECD Countries: Measurement and Highlights. OECD Economics Department Working Paper No. 530. Paris: OECD.

Omonona, B. T. (2009). Knowledge review on poverty and rural development in Nigeria. Strategy Support Program (NSSP). Background Paper. Washington.

Parasuraman, A. and Zeithaml, V. A. and Berry, L. L. (1994). Reassessment of Expectations as a Comparison Standard in Measuring Service Quality: Implications for Further Research. Journal of Marketing, 58, pp. $111-24$.

Parasuraman, A. and Zeithaml, V. A. and Berry, L. L. (1988). SERVQUAL: A Multiple-item Scale for Measuring Customer Perceptions of Service Quality. Journal of Retailing, 64(1), 12-40.

Parasuraman, A. and Zeithaml, V. A. and Berry, L.L. (1985). A Conceptual Model of Service Quality and Its Implications for the Future. Journal of Marketing, 49.

Rahmqvist, M., and A. C. Bara (2010). Patient Characteristics and Quality Dimensions Related to Patient Satisfaction. International Journal for Quality in Health Care 22 (2): 86-92.

Rasch, G. (1960). Probabilistic Models for Some Intelligence and Attainment Tests. Copenhagen: The University of Chicago Press.

Ramamurti, R. (1992). Why are Developing Countries Privatizing? Journal of International Business Studies, 23(2), pp. 225.

Renzetti, S. and Dupont, D. (2003). Ownership and Performance of Water Utilities (Comparison of US, UK and French Public Utilities). Greener Management International, 42, pp. 9 -19.

Rogowski, R., ed. (1998). Democracy, Capital, Skill, And Country Size: Effects of Asset Mobility and Regime Monopoly on The Odds of Democratic Rule. Princeton, NJ: Princeton University Press. 
Rustichini, Aldo, John Dickhaut, Paolo Ghirardato, Kip Smith, and Jose V. Pardo (2002). A Brain Imaging Study of Procedural Choice. Working Paper, Department of Economics, University of Minnesota.

http://www.econ.umn.edu/ arust/ProcCh3.pdf.

Salini, S., and R. S. Kenett (2009). Bayesian Networks of Customer Satisfaction Survey Data. Journal of Applied Statistics, 36 (11): 1177-1189.

Sohail, M. and Cavill, S. (2006). Voice in Infrastructure Services. Water, Engineering and Development Centre (WEDC), Loughborough University.

Teas, R.K. (1993). Expectations, Performance Evaluation, and Consumers' Perceptions of Quality. Journal of Marketing, 57, 18-34.

Tenenhaus, M., E. V. Vinzi, Y. M. Chatelin, and C. Lauro (2005). PLS Path Modelling. Computational Statistics \& Data Analysis 48: 159-205.

Thampi, G.K. (2005). Experiences with Citizen Report Cards in Bangalore, Community Voice as an Aid to Accountability, $20^{\text {th }}$ August 2005.

United Nations (2012). Responding to the Urban Water Challenge. http://www.un.org/en/development/desa/news/sustainable/water-challenge.html [Accessed 8 October 2012].

WHO/UNICEF (2006). Meeting the MDG Water and Sanitation Target: The Urban and Rural Challenge of the Decade. Switzerland: World Health Organization and UNICEF.

Withey, M.J. and Cooper, W.H. (1989). Predicting Exit, Voice, Loyalty, and Neglect. Administrative Science Quarterly, 34(4), pp. 521.

Wold, H. (1982). Systems under Indirect Observation Using PLS. In A Second Generation of Multivariate Analysis: Methods, edited by C. Fornell, 325-347. New York: Praeger.

Zeithaml, V.A and Bitner, M.J. (2003). Service Marketing: Integrating Customer Focus across the Firm, NY: McGraw-Hill.

Zeithaml, V.A., Parasuraman, A. and Berry, L.L. (1990). Delivering Quality Service: Balancing Customer Perceptions and Expectation. New York: Free Press.

ZeithamIL, V. (1988). A Consumer's Perceptions of Price, Quality, and Value, Journal of Marketing, 52 (3). 


\section{Appendix-1 Parameter Estimates}

\begin{tabular}{|c|c|c|c|c|c|c|c|c|c|c|c|c|c|}
\hline \multirow{3}{*}{ Predictor } & & \multirow{2}{*}{\multicolumn{6}{|c|}{ Hidden Layer 1}} & \multirow{2}{*}{\multicolumn{6}{|c|}{ Output Layer }} \\
\hline & & & & & & & & & & & & & \\
\hline & & $H(1: 1)$ & $H(1: 2)$ & $H(1: 3)$ & $H(1: 4)$ & $H(1: 5)$ & $H(1: 6)$ & {$[\mathrm{Y} 1=0]$} & {$[Y 1=1]$} & {$[\mathrm{Y} 2=0]$} & {$[\mathrm{Y} 2=1]$} & {$[\mathrm{Y} 3=0]$} & {$[\mathrm{Y} 3=1]$} \\
\hline Input & (Bias) & .312 & .044 & -.365 & -.666 & -.974 & -.843 & & & & & & \\
\hline Layer & $x 1$ & -.065 & .179 & .188 & .039 & -.286 & -.043 & & & & & & \\
\hline & $x 2$ & .245 & -.446 & -.307 & .415 & -.087 & .009 & & & & & & \\
\hline & $x 3$ & -.069 & -.384 & -.194 & .407 & .034 & .132 & & & & & & \\
\hline & $\times 4$ & .049 & .073 & -.438 & .214 & .283 & -.155 & & & & & & \\
\hline & $x 5 a$ & -.328 & -.355 & .240 & .352 & .027 & .148 & & & & & & \\
\hline & $x 5 b$ & -.394 & -.394 & -.478 & .330 & .199 & -.338 & & & & & & \\
\hline & $x 6$ & .489 & .449 & .083 & -.345 & .253 & .321 & & & & & & \\
\hline & $x 7$ & .164 & .188 & .004 & .487 & -.035 & .110 & & & & & & \\
\hline & $x 8$ & -.283 & -.535 & -.143 & .396 & .330 & .668 & & & & & & \\
\hline & $x 9$ & .085 & -.309 & .233 & -.204 & -.205 & -.281 & & & & & & \\
\hline & $\mathrm{x} 13$ & -.338 & .087 & -.547 & .061 & -.315 & .087 & & & & & & \\
\hline & $\mathrm{x} 14$ & -.139 & .107 & .444 & .184 & .215 & .185 & & & & & & \\
\hline & $x 14 a$ & -.248 & .209 & .100 & .184 & .173 & .837 & & & & & & \\
\hline & $x 15$ & .010 & .487 & .228 & .314 & -.488 & .280 & & & & & & \\
\hline & $\times 17$ & .268 & .400 & .256 & .303 & .141 & -.060 & & & & & & \\
\hline & x24 & .324 & -.086 & .312 & .044 & -.391 & .229 & & & & & & \\
\hline & $x 25$ & .074 & .177 & -.344 & .508 & .321 & -.014 & & & & & & \\
\hline & $x 26$ & -.221 & .452 & -.341 & -.410 & .331 & -.053 & & & & & & \\
\hline & $x 27$ & -.360 & .309 & -.453 & .446 & .343 & -.017 & & & & & & \\
\hline & $x 28$ & -.246 & .428 & -.120 & -.348 & -.025 & -.342 & & & & & & \\
\hline & $x 29$ & -.464 & -.297 & .413 & -.198 & -.169 & .465 & & & & & & \\
\hline & $x 46$ & .307 & -.348 & .217 & -.256 & .194 & .394 & & & & & & \\
\hline & x51 & -.184 & -.240 & -.447 & -.005 & .442 & .197 & & & & & & \\
\hline & Lnx52 & .177 & -.492 & .192 & .315 & -.236 & -.323 & & & & & & \\
\hline & x53 & .531 & .353 & -.411 & .263 & .017 & -.303 & & & & & & \\
\hline & x54 & -.563 & .367 & -.214 & .200 & .706 & .072 & & & & & & \\
\hline & x55 & .222 & .347 & .426 & .218 & -.088 & -.175 & & & & & & \\
\hline & x57 & -.136 & -.420 & -.190 & .291 & .299 & -.108 & & & & & & \\
\hline Hidden & (Bias) & & & & & & & -1.199 & .932 & -1.083 & .961 & -1.640 & 2.011 \\
\hline Layer 1 & $\mathrm{H}(1: 1)$ & & & & & & & .022 & .707 & -.302 & .191 & .190 & .342 \\
\hline & $\mathrm{H}(1: 2)$ & & & & & & & .017 & .598 & .506 & .391 & .279 & .147 \\
\hline & $\mathrm{H}(1: 3)$ & & & & & & & -.185 & -.089 & .071 & .014 & .311 & .224 \\
\hline & $\mathrm{H}(1: 4)$ & & & & & & & -.055 & -.247 & .364 & .364 & .393 & -.424 \\
\hline & $\mathrm{H}(1: 5)$ & & & & & & & .853 & -.105 & -.017 & -.754 & .428 & -.611 \\
\hline & $\mathrm{H}(1: 6)$ & & & & & & & .761 & -.753 & .400 & .273 & .641 & -.096 \\
\hline
\end{tabular}

